\title{
GRUNDTVIGS ALMANAK FOR AARET 1813
}

Udgivet og kommenteret ved Gustav Albeck.

Blandt Grundtvigs Papirer findes i fasc. 505 en lille Universitetsalmanak 》for det Aar efter Christi Byrd $\left.1813 \ll^{1}\right)$. Gr. har - saare primitivt - indskudt (indsyet med en enkelt Traad) ialt 14 Blade (blaaligt Ørholm-Papir, Vandmærke $\varnothing$ \& N). Paa disse Blade har han i Aarets Løb indføjet en Rakke Notater, der undertiden har Karakter af Dagbogsoptegnelser, undertiden af smaa Tilbageblik paa nogle af Aarets Begivenheder. Enkelte Gange bruger han ogsaa Almanakken som Regnskabsbog').

Almanakken har været kendt og benyttet af tidligere Gr.-Forskere, især Rønning og Begtrup (jf. Steen Johansens Bibliografi, I, p. 86, Nr. 217 og IV, p. 109). Derimod har den aldrig været trykt $i$ sin Helhed, og da adskillige, enkelte endog meget betydningsfulde, Optegnelser fra den i høj Grad har Krav paa at blive kendt, har jeg fundet det rigtigt at publicere den in extenso her i Grundtvig-Studier. Den giver os en Række Glimt fra et af Gr.s Skæbneaar, der indledtes med Faderens Død og sluttede med Gr.s hede Ønske om at faa Kapellaniet ved Aggers Kirke ved Christiania, et Ønske, som de store Begivenheder i Januar 1814 gjorde uopfyldeligt.

Den skildrer den bitre Afsked med Udby og præges iøvrigt af Gr.s faste Tro paa, »at Gud (vil) føre det naadefuldt saa, at jeg uden at bekymres maa annamme det daglige Brød, og komme der, hvor Han seer, at ved mig Meest udrettes til Hans Fre og Riges Udbredelse, og ledsage mig ved sin Hellig Aand, saa at jeg, som prædiker for andre ei selv skal vorde forskudt . . .«

Bl. Ir: 3die kom Liselille ${ }^{3}$ ) hid.

$$
\text { Januar. }
$$

5 te Kl. $3 \frac{112}{2}$ døde salig Fader sagte. Han gik med de Vise af Østen efter Stjernen til Jesus. Det give os alle Gud Naade til for Jesu Skyld.

Bl. 1v: I. J. N.

2rdr 3 Mk Rbpg

25de Reiste jeg til Khvn. Fik af Moder 44 rdr. slette Penge. 7rdr. 51/3 Sk. Rgbk.

$$
\text { I. J. N. }
$$

B1. 2r: 2den 200rdr. slette Penge af Seidelin.

53 rdr. 2 mk Rgbp.

8 de af Moder 40rdr.

Grd. 4 mk Rgbp.

2 Ligprakener [61/6] $\left.4^{1 / 6} \mathrm{Rbd}^{4}\right)$. 
I. J. N.

Bl. 2v: Det var nok omtrent ved denne Tid jeg førstegang i lang Tid tilskrev Olsen ${ }^{5}$ ). Gud være lovet for sin Velsignelse.

Martii

I. J. N.

Bl. 3r: 6te Fik jeg i Jesu Navn det Ny Testamente udlæst i Aar førstegang $^{6}$.

15. fulgte jeg Lise til Olstrup og kom igien Dagen efter til Onsdag. Jeg fandt et mærkeligt Brev fra $0 . .^{7}$ ), og som udentvivl er værd (at) glædes over her og hisset.

Bl. 3v: Jeg svarede ham strax ei heller kort. Gud lægge sin Velsignelse til, saa han maa lære at tro eenfoldelig, efter Ordets Lydelse. I Jesu Navn Amen.

1 Rdr. Rbpg. fra Indsk.

Først i April skrev jeg Præsten $\mathrm{Holm}^{8}$ ) et langt Brev til om meget Christen Tro angaaende, som Svar paa Hins. Han synes langt fra enfoldig Tro, dog Herren er stærk og viis.

Bl. 4r: Skiærtorsdag skrev jeg Hersleb et langt Brev til om den bogstavelige ordrette Forstand af Bibelen. Faderen drive ham ved sin Hellig Aand til at troe eenfoldelig paa Guds Ord:

Guldberg! G.H.H.

Af min Moder 2rdr. $4^{\text {mk }}$ Rbkpg.

Herren gav, Herren tog, Herrens Navn være lovet!

Bl. 4v: 25de Confirmerede jeg 21 Børn i Ørslev Kirke, Gud være lovet! med Hjertens Glæde til Opbyggelse! Give Gud i Jesu Navn til Frugt, som Faderen æres ved!

30te fik jeg atter ved den Helligaands naadefulde Bistand det $\mathrm{Ny}$ Testamente giennemlæst. Gud velsigne hver Læsning i Jesu Navn.

Bl. 5r: til Hans Ere og Ordets mægtige Seier, til Opbyggelse og Salighed for mig selv og Andre!!!

Det var mig underligt efterat jeg i Enden af Octbr 1813 kom ind til Byen, endeel Kald vare ledige, men hvilket af dem jeg skulde søge, syntes mig saare uvist, da Intet fortrinlig syntes mig passelig med min Tanke om min beskikkede Gierning. Jeg søgte da intet, men det blev min Overbevisning, at blev enten Præstøe Kald eller et Præsteembede i Cristiania ledig, da vilde jeg søge, hint fordi min Moder er der, jeg var nær ved mine gamle Menigheder og

Bl. 5v: ei langt fra Khvn, det sidste fordi Norges Høiskole er der, og mig aabnedes nærmere Indgang hos Nordmænd. DS ${ }^{9}$ ) 15 de Novbr. faldt mig den Dag i Haanden hvor det meldes at Kapellaniet til Aggers er ledigt, og det faldt mig paa Sinde: Der. Da jeg næste Morgen opslog min Bibel faldt Øiet paa Jobs. 11.17: og Dagens Kapitel i det N. T. var Joh. 8 som begynder: Og Jesus gik til Oliebjerget. Der jeg havde begyndt at skrive dette, bragtes mig Brev 
fra min elskede Hersleb. Jeg synes i alt Dette at see Herren vinke. - Dog hvo kiender Herrens Sind? Hans Villie skee ${ }^{10}$ ).

Bl. 6r: Den 12te Aug. visiterede Biskop Münter i Udbye og Alt gik, Herren være lovet! godt langt over Formodning. Jeg prækede efter 1. Pet. 5.2-4 om Hvordan vi skal føde Guds Hjord for at bestaa naar Overhyrden aabenbares. Uventede vare tilstæde $\mathrm{Hr}$. Homann fra Hammer, som har staaet Fadder til mig, og vilde høre den

Bl. 6v:

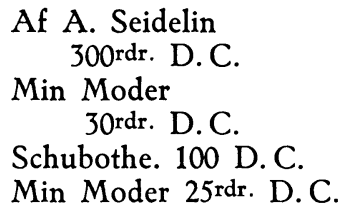

Bl. 7r: Christendom han elsker ${ }^{11}$ ), Hr. Varthoe fra Snesere ${ }^{12}$ ) Hr. Vestengaard fra Sverdborg ${ }^{13}$ ) og Hr. Møller fra Kiøng ${ }^{14}$ ), hvilke især de to første vel kun vilde høre, hvad jeg dog uden at skamme mig, kunde faa isinde at sige naar der vare oplyste Tilhørere. - Da jeg havde min Prædiken færdig kom det mig for, at den ei i alle

Bl. 7v: Maader var passelig, uden der vare endeel Præster tilstæde af adskillig Bekiendelse, og de kom.

8nde Søndag efter Trin var Prof. Sandal ${ }^{15}$ ) i begge Kirker og jeg prædikede om at vogte sig for de falske Propheter. Gid det intet ont Forvarsel maa være. -

Bl. 8r: (ubeskrevet!)

Bl. 8v: 9de Sønd. efter Tref. holdt jeg i Jesu Navn min Afskedsprædiken om hvordan en Husholder maa være tilmode naar Hans Herre tager Husholdningen fra ham. Mag. Møller ${ }^{16}$ ) var i Kirke. - Gud være lovet for sin naadefulde Bistand.

21 de Aug. reiste jeg til Khvn. Gud styre alt efter sin Villie!

Af min Moder 200rdr. D. C.

Af Bogtrykker Høike $120 \mathrm{~d}$.

Bl. 9r: Mit Ny Testamente 3die Gang giennemlæst. Gud! lad mig giemme Dit Ord i mit Hjerte, at jeg ei skal synde imod Dig!

I Jesu Navn.

d. 7de kom Prof. Sandal. Saa stunder da Skilsmissen til fra Udbye, og hvorhen jeg skal fløtte Staven, det veed kun Gud i Himlen. Herre leed mig paa en evig

Bl. 9v: Vei! det er mit Hjertes Bøn. Gud føre det naadefuld saa, at jeg uden at bekymres maa annamme det daglige Brød, og komme der, hvor Han seer, at ved mig Meest udrettes til Hans Ære og Riges Udbredelse, og ledsage mig ved sin Hellig Aand, saa at jeg, som prædiker for andre ei selv skal vorde forskudt. I Jesu Navn.

Bl. 10r: Den ottende Septbr., da Gud lod mig fylde mit 30te Aar, var jeg hos Kongen, jeg bad ham efter det bestemte, naadige Løfte, han gav mig i Sommer, at tænke paa min Befordring, og Gud gav mig Frimodighed til at sige mit Ønske, at ansættes ved Norges Høiskole. 
Jeg sagde, efter at have bedet om Tilladelse til at tale som det laae mig paa Hjertet. Deres Majestæt har sikkert (for) selv fornummet det, det staaer ikke til i Landet som det burde og Fæderlandskiærlighed.

Bl. 10v: er ei tilstæde, jeg venter Meget af den Høiskole D.M. har stiftet i Norge, jeg veed jeg har mellem Flere været foreslaaet til Professor i Historien og det ønskede jeg at blive. Jeg tør sige det, fordi jeg tør vidne, at for min egen Skyld er det mig ligegyldigt, om jeg [staa] sidder som Præst $i$ en Afkrog eller staaer som Lærer paa en Høiskole, men jeg troer der at kunne virke meest. Gientagne Gange lovede Kongen at tage den Ting i Betænkning, og jeg gik hjem med Tak til Gud, fordi det undtes mig at udsige, hvad jeg anseer for Ret, nu vil jeg med

Bl. 11r: Guds Hjelp rolig vente Udfaldet, vis paa at Hans Villie skal skee og at det er den eneste gode. Gud give mig ved sin Hellig Aand Naade til altid at være et villigt Redskab i Hans Haand, ikke søge min egen Fre, ikke søge at tækkes Menneskene, men den Gud som prøver Hjerterne. Samme Dag digtede jeg Verset ved Karen Bjørns Minde med andægtig Glæde ${ }^{17}$ ).

Den 25de Septbr. reiste jeg fra Khvn. og kom d. 27de til Udbye Paa den Tid endte jeg det Ny Testamentes Læsning 4de Gang i Aar, Gud velsigne sit Ord paa mit Hjerte.

Bl. 11v: Den 27de Octbr. udfløttede jeg tilligemed min kiære Moder af Udbye Præstegaard, og har da nu slet intet Sted som jeg kan kalde mit Hjem paa Jorden. Vort Borgerskab er i Himlen og visselig det trænger vi haardt til at mindes om; men er det Guds Villie da ønskede jeg dog lidt visse Værelser og en vis Stilling. Dog Herren vil bære Omsorg for os, naar vi kun vælte vor Omhu paa Ham.

Den 29de reiste jeg til Khvn med min Lise! Jeg kan ikke noksom takke Gud, for den Føielighed alle Omstændigheder maatte udvise ogsaa paa denne

B1. 12r: Reise, det var saa, at Gud paa eengang vilde beskiæmme og trøste mig. Beskiæmmet blev jeg, thi den Fløtning havde virkelig foruroliget mig, og trøstet blev jeg, da det var som et Ord: vær frimodig! Jeg vil ikke slaae Haanden af dig og ingenlunde forlade dig.

Paa alle Helgens Dag prædikede jeg i Guarnisons Kirken og udsagde at vi trænge til en Reformation ${ }^{18}$ ). Man skulde mene, at Sligt var let sagt, da jeg har sagt noget Lignende saa tit i Bog, men visselig er det ei saa let at sige en ubehagelig Sandhed Ansigt til Ansigt $i$ en stor Menighed som at skrive den.

Bl. 12v: Dog, jeg ansaae det ei heller for let, og den Gud, paa Hvem jeg forlod mig, stod mig kraftelig bi. Lovet være vor Herres Jesu Christi Fader, hvis Kraft fuldkommes i vor Skrøbelighed. Det er i Dag Mortens Dag, Morten Luthers Fødselsdag. Gud velsigne den til at vorde mærkværdig i Hans Husholdning til Hans Kirkes Fornyelse og Ordets Gienfødelse iblandt os. Amen i Jesu Navn. Amen.

I forrige Uge laante jeg 400rdr. D. C. af Hr. Major Aagaard ${ }^{18}$ ), hvilke, om Gud vil, skal betales til 11. Decbr. Termin.

Ere betalte 11. Decbr. 
I. J. N.

Bl. 13r: Den 26de Novbr kom $\mathrm{O}$ her til mig han var haltende men Gud gav mig Naade til at størke ham. Den samme vor Herres Jesu Christi Fader veilede og bekræfte ham ved sin Hellig Aand i al Sandhed til Gudfrygtighed i Jesu den Korsfæstedes Navn. Amen. Den 16de fuldendte jeg engang endnu det Ny Testamentes Giennemlæsning. Gud være lovet og takket for sit hellige Ord, thi kun Hans Ord ere sande og trofaste. Han give os dem for Jesu Døds Skyld i Mund og Hjerte ved sin Helligaand saa at vi maa tale med Frimodighed som Han vil, og at vi som prædiker for Andre, skal ikke selv forskydes.

2. Adv. prædikede jeg i Stokhuset og i Guarnisons Kirken ${ }^{20}$ ). Herren være

Bl. 13v: storligen lovet for sin Hellig Aands naadefulde Bistand. Den 16de fik jeg Brev om at være Capellan i Alsted ${ }^{21}$ ); mig synes ei, at det skal saa være, dog styre Gud mine Tanker og bøie mit Hjerte til at giøre ei hvad jeg, men hvad Han vil. Amen!

Første Juledag prækede jeg til Aftensang i Hellig Geist Kirke for en stor Forsamling, jeg prækede om den Juleglæde, som vore fromme Fædre følte, og hvilken vi knap have Skyggen af.

Bl. 14r: St. Stephans Dag prækede jeg i Stokhuset til Høimesse om Guds Miskundhed og Straffedomme. Aldrig har en Kirkesang gaaet mig saa til Hjerte, som de arme Fangers efter Prædiken om det dyrebare Jesu Navn. Gud lade det blive et saligt Navn for saa mange af dem som muligt er.

Til Aftensang prakede jeg i den Herre Zebaots Kirke for en mindre Samling end ellers, om det Indtryk den hellige Stephans Betragtning maa giøre paa Crist-

Bl. 14v: ne. Det var (en?) af mine bedste Prædikener.

O! Himmelske Fader! Du, som saa faderlig haver ført og hjulpet mig i det forgange Aar, vær Du ogsaa ved Din Hellig Aand kraftelig med mig $\mathrm{i}$ det ny, lad mig som et villigt Redskab giøre altid det, hvorved Du mest æres, Dit Rige udbredes og vor Salighed befordres, ja, o, Gud saliggiør mig for Jesu Christi hellige Pines og Døds Skyld.

Amen!

\section{Noter:}

1) Almanakken for 1813, »som er det første Aar efter Skud-Aar«, var »beregnet og sammenskrevet《 af Thomas Bugge, »Prof. Astron. og Ridder《 og trykt hos Schultz.

$\left.{ }^{2}\right)$ Grs. Notater om hans Pengesager er præget af Forordningen af 5. Januar 1813, efter hvilken en Rigsbankdaler var lig med 6 Rigsdaler kurant. I sine Notater omregner Gr. Rgdlr. kur. (af Gr. betegnet med Udtrykket »slette Penge«) til Rigsbankdaler (Gr.: Rigsbankpenge). I sin Beregning for 25. Januar regner Gr. forkert. De $44 \mathrm{Rdr}$. slette Penge skulde i ny Mønt udgøre 7 Rdr. og 2 Mk. Rbpg. De 2 Mk. udgør 32 Skilling, og Gr. 
dividerer ved en Fejltagelse Markbeløbet en Gang til, hvorved han kommer til Beløbet 7 Rdr. 51/3 Sk. Rbpg.

Beløbene paa Blad 2r (under 2.(Februar)) er fuldt korrekt udregnede.

Som det ses, opfører Gr. nogle Indtægter fra sine Forlæggere og Trykkere. Seidelin (VK 1812), Schubothe og Høicke.

3) Gr.s Kæreste Lise Blicher.

$\left.{ }^{4}\right)$ Her synes der at foreligge en Rettelse, ikke en Omregning.

5) Christen Olsen, der havde sendt Gr. et Kondolencebrev i Anledning af Johan G.s Død. Brevet var dateret Kolding d: 23. Jan. 1813, Breve I, prs. $124-125$.

$\left.{ }^{6}\right)$ Holger Begtrup: Gr. som Bibelkristen, p. 45-46, har samlet alle de Steder i Almanakker, hvor Gr. fortæller om sit flittige Studium af NT.

$\left.{ }^{7}\right)$ formentlig ovennæunte Christen Olsen.

$\left.{ }^{8}\right)$ A. K. Holm. Jf. Breve I, p. 148-159. Gr.s Brev til H. synes tabt.

${ }^{9}$ ) DS: Danske Statstidende $=$ Berlingske Tidende.

$\left.{ }^{10}\right)$ Jf. Gustav Albeck: Omkring Grundtvigs Digtsamlinger. Acta jutlandica, 1955.

11) Peter Jacob Homann, Sognepræst i Hammer-Lundby.

12) J. O. S. Warthoe, Sognepræst i Snesere.

13) F. L. Westengaard, Sognepræst i Sverborg.

14) Tage Christian Müller, Sognepræst i Kiøng, Hammer Herred.

15) Henrik Paulin Sandal. Han havde opnaaet Embedet i Udby efter Johan Gr. - Han havde tjent i Artillericorpset og været Lærer v. Landcadetakademiet. D. 12. Maj 1813 var han blevet udnævnt til tit. Professor.

${ }^{16}$ ) Formentlig Sognepræst, Magister Rasmus Møller fra Købelev, Poul Martin Møllers Far. (Jf. Breve I, p. 125 f og p. 130.

${ }^{17}$ ) Trykt i Rønning, II, I, p.

18) Prædikenen trykt i BP, 1816, p. 23-42, US, III, p. 259-268.

${ }^{19}$ ) Just Michael Aagaard, Ejer af Iselingen.

${ }^{20}$ ) Prædikenen trykt i BP, 1816, p. 43-66 og i US, III, p. 269-280.

${ }^{21}$ ) Formentlig Alsted-Fjenneslev. 